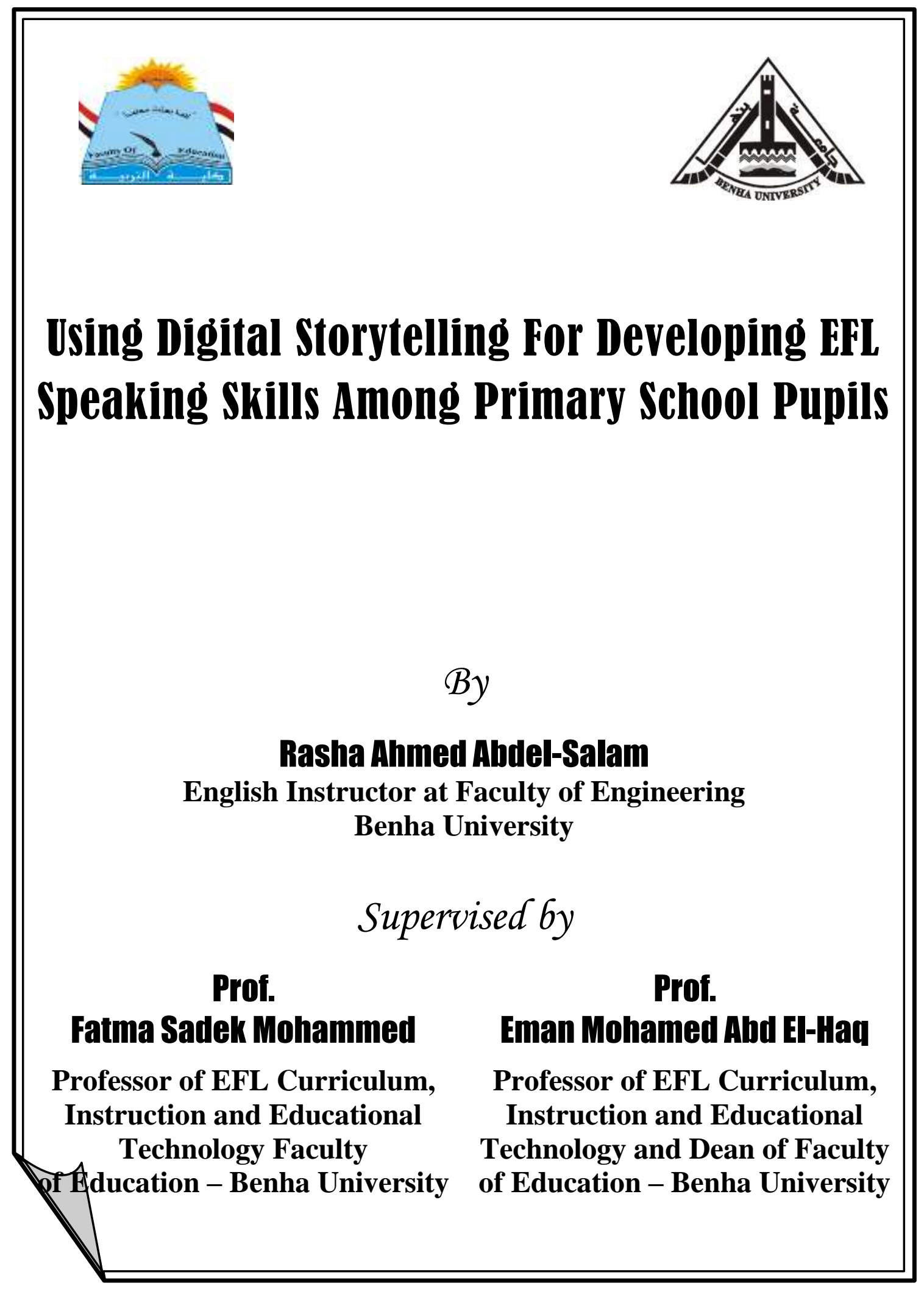




\title{
Using Digital Storytelling For Developing EFL Speaking Skills Among Primary School Pupils
}

\author{
By \\ Rasha Ahmed Abdel-Salam
}

English Instructor at Faculty of Engineering

Benha University

Prof.

Fatma Sadek Mohammed

Professor of EFL Curriculum,

Instruction and Educational

Technology Faculty of Education

Benha University

\section{Supervised 6y}

\author{
Prof. \\ Eman Mohamed Abd El-Haq \\ Professor of EFL Curriculum, Instruction \\ and Educational Technology and Dean \\ of Faculty of Education \\ Benha University
}

\begin{abstract}
This study aimed at improving EFL speaking skills among sixth year primary school pupils through using digital storytelling. The participants of the study consisted of 30 sixth year primary school pupils in Alshahid Abd EL-Moneem Riyaad Primary School, Benha, Qaliupia Governorate. The study followed the two groups (experimental and control groups) design. The instruments of the study included an EFL speaking test(pre and post tests). The Pre test was administered to the two groups of sixth year primary school pupils. The pupils were taught using digital storytelling to develop their EFL speaking skills . Then, the post test was administered. Results of the study revealed that the experimental group's EFL speaking skills improved significantly than the control group as a result of using digital storytelling . Therefore, it can be concluded that using digital storytelling was effective in developing EFL sixth year primary school pupils speaking skills.
\end{abstract}

Keywords: EFL Speaking Skills - Digital Storytelling (DST). 


\section{Introduction}

English has become an international language. Language is a tool of expressing feelings and thoughts from speaker/writer to listener/ reader. Language learning involves mastering the four language skills: listening, speaking, reading and writing. These skills naturally appear together in every English class, even in the EFL context. These skills are communication skills that are important in the curriculum. Along with the strengthening position of English as a language for internartional communication, students need to be proficient in those skills.

English is one of the most widely spoken languages almost every day in the world. Speaking is the process of building and sharing meaning through the use of verbal and non-verbal symbols, in a variety of contexts. Speaking is a crucial part of second language learning and teaching. Despite its importance, for many years, teaching speaking has been undervalued and English language teachers have continued to teach speaking just as a repetition of drills or memorization of dialogues. However, today's world requires that the goal of teaching speaking should improve students ' communicative skills (Kayi, 2006).

Luoma (2009) clarified that speaking could reflect one's personality, inner image , thoughts and knowledge of the world around us . Speaking is an important factor for language acquisition. It needs to be mastered by everyone, as by speaking, one can convey message , express his feeling and give opinion. Speaking is a speech production that becomes a part of daily activities which involve interaction. Speaking skill is the most important skill in language learning which gives learners opportunity to practise, speak fluently and arrange sentences (Elnada, 2015).

Speaking is one of the four macro skills to be developed as a means of effective communication in both first and second language learning contexts. There are a number of factors relating to speaking 
skills to be considered for effective English speaking performance; Pronunciation, vocabulary, and collocations are singled out as important factors to be emphasized in building fluency for EFL speakers. Providing students with a variety of situations and frequent speaking tasks plays a significant role in the improvement of students' fluency when speaking ( Boonkit, 2010).

Bashir, Azeem and Dogar ( 2011) indicated that many language learners regard speaking ability as the measure of knowing a language. These learners define fluency as the ability to converse with others, much more than the ability to read, write, or comprehend oral language. They regard speaking as the most important skill they can acquire, and they assess their progress in terms of their accomplishments in spoken communication. Language learners need to recognize that speaking involves three areas of knowledge:

- Mechanics (pronunciation, grammar, and vocabulary): Using the right words in the right order with the correct pronunciation.

- Functions (transaction and interaction): Knowing when clarity of message is essential (transaction/ information exchange) and when precise understanding is not required (interaction/ relationship building).

- Social and cultural rules and norms (turn-taking, rate of speech, length of how to take into account who is speaking to whom in what circumstances, about what, and for what).

Speaking is one of the important skills to master . It requires different abilities needed to be produced at the same time. These abilities are fluency, accuracy, comprehensibility and complexity.

\section{Fluency}

Oral fluency is one of the most salient markers of proficiency in a second language. The term 'fluency' has a range of meanings, the most 
common of which is related to 'high proficiency, ' that is, an excellent grasp of the vocabulary and grammar of a language (Rossiter et al. , 2010). According to Brown(2000)and Torky(2006) there are some features that speakers use to speak fluently such as making pauses long and not hesitating and filling their pauses, only in transition point, they make pauses . Also, using long runs of syllables and words between pauses and allowing the stream of the speech to flow.

\section{Accuracy}

Harmer (2010) implied that accuracy is the degree of correctness which a student achieves when using grammar, vocabulary and pronounciation . In addition to that, West(2013) confirmed that students ' accuracy should not be corrected in front of their colleagues in the class , because those students consider this correction as a difficult test to their ability to speak accurately in the class. Richards(2006) stated that there are activities focusing on accuracy such as :

- Reflect classroom use of language.

- Focus on the formation of correct examples of language.

- Practice language out of context .

- Practice small samples of language .

- Do not require meaningful communication .

- Control choice of language.

\section{Comprehensibility}

According to Munro and Derwing (1995), intelligible and comprehensible both mean understandable. The term comprehensibility refers to the listener's perception of the ease or difficulty with which they can make out a speaker's meaning, often measured by a rating on a 9-point likert scale. Inteligibility refers to the extent at which listeners can correctly identify the words they hear. 


\section{Complexity}

Complexity is 'the extent to which learners produce elaborated language' (Ellis \& Barkhuizen, 2005, cited in Khatter, 2012) and is often concerned with syntactic and lexical aspects of narrative performance. Measures for syntactic complexity include: the number of subordinate clauses per Complexity clause (Wigglesworth, 1997); the number of words per T-unit (Bygate, 2001). The number of clauses per C-unit (Robinson, 2001), and the number of subordinate clauses per T-unit . The number of words per unit and the amount of subordination appear to be the two syntactic complexity measures that are most commonly used (Inou, 2009).

Linguistic knowledge plays an important role in oral production. If any feature from this knowledge is lacking or poorly performed, students can find problems within their speaking skills. These difficulties are due to lack of vocabulary, pronounciation mistakes, and grammar mistakes (Thornbury, 2005). Furthermore, Fuente (2003) indicated that learners whose English is not their first language may have difficulties in communicating with others and in understanding academic papers due to limited vocabulary.

In addition to that, psychological barriers are another challenge that faces EFL learners in developing speaking skills. Psychological barriers are the psychological negative emotions that limits learner's performance. Learners may experience different psychological barriers such as lack of self-confidence (Ozen\&Bindak, 2012), anxiety (Virginia, et al. , 2009), and fear of making mistakes(Ur, 2000).

As a result of the importance of speaking skills, some studies were conducted to investigate them and develop with different methods and approaches such as (Ali, 2010; Selim, 2011; Diyabb, 2013; Helwa 2013). Consequently there is a need today to move from the traditional way of teaching to new approaches which depend on technology to help 
students to develop their speaking skills.

Educational environments must be adapted to meet the demands of the $21^{\text {st }}$ century skills. These twenty first century skills include: digital literacy, inventive thinking, effective communication and high productivity (Jakes, 2006). Educational techonology can provide EFL teachers with valuable tools and develop the $21^{\text {st }}$ century skills, which is a primary reason why integration of techonology in Education has become a major area of interest over the last decade.

Computer- assisted language learning(CALL) has become widely popular in recent years. Using computers for teaching English as a foreign language (EFL) has been delineated at length in the literature . EFL teachers seem to be well aware of the need for CALL in today' s language classroom (Heffernan, 2005). Traditional approaches to language teaching and learning have been challenged by new and innovative approaches based on the latest advances in computer and Internet technology. The origin of storytelling is absolutely ancient . It is a simple but powerful method to help students to make sense of the complex and unordered world of experienc by crafting story lines. Within the last 10 years, digital cameras, editing software, and electronic media outlets have encouraged teachers to utilize many more approaches and tools to help students to construct their own knowledge (Standley, 2003). One of these powerful approaches to multimedia production is digital storytelling.

Digital stories are technology application that is well-positioned to help teachers overcome some of the obstacles during the teaching process in their classrooms. It takes the same steps of the tradition process of storytelling from selecting a topic, conducting some research, writing a script, and developing an interesting story. This material is then combined with various types of multimedia, including computerbased graphics, recorded audio, computer-generated text, video clips, and music so that it can be played on a computer, uploaded on a web 
site, or burned on a DVD. The combination of powerful, yet affordable, technology hardware and software meshes perfectly with the needs of many of today's classrooms, where the focus is on providing students with the skills they will need to thrive in increasingly media varied environments (Riesland, 2005).

According to Bull and Kajder (2004), there are seven elements in the digital story; the first three have to do with the construction of the story content; the last four have to do with the technical construction of the digital story:

1- point of view: the main point or specific realization that a student tries to communicate within his or her story.

2- Dramatic question: the key question that will be answered by the end of the story and keeps the audience member's attention.

3- Emotional content: writing that will take hold of audience member's attention and engage them emotionally.

4- The gift of the voice: narration of the text, including emotion and inflections that give greater meaning to the story and aid in the audience's understanding.

5- Soundtrack: thoughtfully selected sounds and music will add further emotion .

6- Economy: many stories can be illustrated effectively with a small number of images or video and a fairly short text.

7- Pacing: the rhythm of a story and how slowly or quickly it moves.

Digital storytelling consists of four phases: pre-production, production, postproduction; and distribution (Yang \& Wu, 2012). Pre production includes five steps: a) posing questions in authentic scenarios, b) exploring topical information, c) writing the script and eliciting peer review, d) performing oral storytelling, and e) designing a story map and story board. At the beginning of class, the instructor poses certain questions about a topic based on contexts or experiences and decide upon 
a topic. Next, students research the topic for information to write scripts which reflect a logical story or sequence of events. Afterward, a story map is designed to illustrate the main components of the story and their relationship to the overall narrative. For instructors, story mapping provides a basis for immediate assessment of student's stories and provides feed- back on how to improve weaker elements of their stories. In addition, students represent their stories in a story board format, arranging the sequence of scenes, effects and other digital components.

Each task in this pre-production phase is paper-based, requiring focus on the content rather than multimedia elements. Writing scripts and story treatment is a key process for creating digital stories since the final product is media - based. During the Production phase, students prepare multimedia elements and record their own voices. Then, in the postproduction phase, the content is arranged and edited into a digital story.

During the distribution phase, students share their comments and digital stories with others. The dynamic process of creating digital stories develops a deeper connection with the subject matter being learned as well as relevant extra - curricular experiences.

According to Rokni and Qarajeh(2014), storytelling is regarded as a comprehensive device because speakers use their background and linguistic knowledge to create a message that will be meaningful to the intended audience. Speakers activate schemata from specific context to convey meaning for a definite purpose with an intended audience in mind . Storytelling helps speakers to be able to comprehend meaning that is conveyed at a level beyond that of sentence, to have the choice of what to say and how to say it, and to have an objective in mind while talking. Moreover, storytelling helps students improve their speaking skills, their communication skills, vocabulary, grammar, pronounciation and accent. 


\section{Context of the problem:}

In spite of the importance of EFL speaking skills, there is a lack in these skills among pupils of the primary stage. This problem was indicated by the results of the following studies (Seif El-Naser, 2003; ElBasel, 2008 ;Khatter, 2012 ; Farag, 2015; AL-Kady, 2016).

Needless to mention that most of the English language teachers concentrate on writing and reading skills, and pay less attention to listening and speaking. Major reason teachers declare is due to the nature of examination systems which concentrate on the writing skills(Abdel Khalk , 2011).

To document the problem of the present study, a pilot study was conducted by the researcher to find out the lack of speaking skills among sixth year pupils at the primary stage. The pilot study was conducted in 2016 . The participants were30 pupils of sixth year of Salah Salem primary school in Al-Sharqua Governorate. The pilot study consisted of an EFL speaking test prepared by Farag, (2015) and a rubric to score the test. The EFL speaking test consisted of four questions that students were asked to answer. The results showed that there is a lack in EFL speaking among sixth year pupils at the primary stage. Thus, the present study suggests using digital storytelling in developing some EFL speaking skills among sixth year primary school pupils.

Out of the pilot study, it has been noticed that pupils hesitate to speak, there are many mistakes in pronunciation and most of pupils preferred to keep silent, also expressing the ideas in unclear sentences. Egyptian EFL classrooms have many problems in teaching EFL speaking skills and can't provide pupils with opportunities to practise EFL speaking. These problems are exemplified in the dominance of teacher-centered teaching approaches, paper -based examinations and pupils' lack of interest towards language. Furthermore, pupils do not have enough vocabulary reqired to speak about common speeches, 
pupils speak slowly and take much time to arrange statements, pupils have weak syntax and pronunciation, pupils'oral English is of a bad quality, they lack self-confidence, class circumstances do not support verbal activities.

\section{Statement of the problem:}

There is a lack in the EFLspeaking skills among primary school pupils.

\section{Questions of the study:}

To face this problem, the present study is an attempt to answer the following questions:

1- what are the EFL speaking skills required for sixth year primary school pupils?

2- What are the features of digital storytelling used for developing EFL speaking skills for primary school pupils?

3- What is the effectiveness of using digital storytelling in developing EFL speaking skills among sixth year pupils at primary stage?

\section{Delimitations of the the study}

This study was delimited to the following:

- A group of sixth year pupils at primary stage.

- Some EFL speaking skills required for sixth year pupils

\section{Method of the study}

This study utilized the experimental - control pre-post test design.

\section{Participants of the study}

Participants in the present study were $(n=60)$ sixth year primary school pupils at Alshahid Abd EL-Moneem Riyaad Primary School in Benha Educational Zone, Qaliopia Governorate in the second term of the school year 2018-2019. They were divided into two groups 
(experimental and control group). Each group consisted of ( $\mathrm{n}=30$ )pupils. Sixth year primary school pupils were selected because they are at the end of the primary stage ;therefore they are conscious and can understand the stages of implementing digital storytelling.

\section{Instruments and Materials of the study.}

\section{A) The EFL Speaking skills checklist:}

The EFL speaking skills included in the checklist in its initial form were derived from the directives of the Ministry of Education for general primary schools for the school year (2012) and through reviewing the literature related to the area of EFL speaking skills .

The checklist of the EFL speaking skills was submitted to a panel of jury members EFL specialists at faculty of education $(n=12)$ to identify its validity and to determine the degree of importance of each skill. Moreover, the jury members were requested to add, omit or modify to the checklist any comments they considered important. The initial form of the checklist contained twenty -five micro skills which were modified into nineteen micro skills.

\section{B) The EFL speaking skills Pre-Post tests.}

The purpose of EFL speaking pre-post tests was to measure pupils' EFL speaking skills before and after implementing the intervention to estimate its effect on developing EFL speaking skills among sixth year primary stage pupils.

The speaking tests included the following questions: Question one was designed to measure fluency skills and consisted of (two topics to choose one of them). Question two was divided into three parts: part one was designed to measure pronounciation and intonation. Part two was designed to measure grammar. Part three was designed to measure 
vocabulary. Question three was designed to measure comprehensibility. Finally question four was designed to measure complexity. A rubric was used to score the tests.

\section{Piloting the Test}

Thirty pupils, other than the subjects of the study participants, were assigned for piloting the test. They were from one class in AlShaheed Abd El-Moneem Riyaad, Qaliobia Governorate at the second term of the academic year 2018/2019.

\section{Test Validity}

Two methods were used to ensure the validity of the EFL speaking test: face validity and content validity.

\section{Face Validity}

To ensure face validity of the EFL speaking pre-test, it was developed through reviewing previous literature and related studies on the field of EFL speaking assessment.

\section{Content Validity}

To measure the test face validity, the first version of the test was submitted to a panel of EFL specialists in EFL curricula and instruction $(\mathrm{N}=10)$ to evaluate each question in terms of covering the specified subskills, sufficiency of the number of questions, clarity of the test instructions and items and suitability of the test for the pupils' language level. Most of the jury members accepted the test as it was suggesting that it does not need any modifications either by adding or omitting any of the test items. However, few jury members suggested some changes in phrasing the questions. Except for this, the jury members indicated that the test has clear instructions and is appropriate for measuring what it is intended to measure. Accordingly, it could be said that the EFL speaking test has face validity 


\section{Test Reliability}

For estimating the reliability of the EFL speaking test, the test was administered to a group of sixth year primary school pupils at Alshaheed Abd ELMoneem Riyaad, Alqaliobia Governorate $(n=30)$ (other than the experimental group who received the treatment) during the second semester of the academic year 2018/2019. Then, it was administered to the same group again after two weeks. The Pearson correlation coefficient between the two administrations was $(0.912)$ which is significant at the 0 . 01 level. This means that the EFL speaking test is reliable.

\section{C-A Rubric for scoring the pupils's performance in EFL speaking tests.}

The rubric was used to score the pupils' performance in the EFL speaking tests. The rubric consisted of four parts scored on a five points Likert scale ranging from "5" to "1" marks. The pupils were given a rating between 1 to 5 for their performance in the EFL speaking test . The pupils were given 5 marks when their performance is high. They were given 4 , if they have minor mistakes. They were given 3 if they have some mistakes. They were given 2 , if they usually did mistsakes. And 1 mark when their performance is low.

\section{Intervention:}

The treatment consisted of (14) sessions; The first was devoted to the pre-test. The second was an interview with the participants and a lecture about digital storytelling and how to carry it out. while the remaining sessions concentrated on how to implement the digital stories in the classroom, how to make a storyboard and story map. The participants learnt how to collaborate with each other in making their stories and how to comment on their peers' work. 


\section{Results of the Study:}

The researcher conducted paired sample t-test on the pupils' scores to compare the means of the pupils' scores on the pre-posttests by means of the Statistical Program for Social Sciences (SPSS v. 18). The following table presents the pupils' means, standard deviation, $t$-value and level of significance. The results support the following hypothesis.

There is a statistically significant difference at the $(0.01)$ level between the mean scores of the experimental group and that of the control group in EFL speaking skills on the post administration of EFL speaking test in favor of the experimental group. "

Table(1): Findings of t-test of the EFL speaking skills post

administration for the experimental and the control group

\begin{tabular}{||c|c|c|c|c|c|c|c|c||}
\hline $\begin{array}{c}\text { Main } \\
\text { skills }\end{array}$ & Group & .No & Mean & $\begin{array}{c}\text { Std. } \\
\text { Deviation }\end{array}$ & $\begin{array}{c}\text { t- } \\
\text { value }\end{array}$ & DF & $\begin{array}{c}\text { A } \\
\text { Sig }\end{array}$ & $\mathbf{\eta 2}$ \\
\hline $\begin{array}{c}\text { The overall } \\
\text { speaking }\end{array}$ & Experimental & 30 & 71.83 & 10.89 & $\begin{array}{c}24 . \\
58\end{array}$ & $\begin{array}{c}0 . \\
01\end{array}$ & $\begin{array}{c}0 . \\
91\end{array}$ \\
\hline & Control & 30 & 22.23 & 1.95 & 55 & & \\
\hline
\end{tabular}

Table (1) indicates that the mean scores of the study participants of the experimental group in the post administration of the EFL speaking skills was higher than the participants' mean scores of the control group, where t-value is $(24.55)$ which is significant at the $(0.01)$ level. Thus this hypothesis is supported.

The following table presents the pupil's mean scores, standard deviations, t-value and level of significance in the four sub-skills of the EFL speaking skills in the post-test of the experimental and the control group. 
Table (2): Findings of t-test of the EFL speaking skills post-test in each sub-skill of the experimental group and the control group.

\begin{tabular}{|c|c|c|c|c|c|c|c|c|c|}
\hline $\begin{array}{l}\text { Main } \\
\text { skills } \\
\end{array}$ & Sub-skills & Group & .No & Mean & $\begin{array}{c}\text { Std. } \\
\text { Deviation } \\
\end{array}$ & $\begin{array}{c}\text { t- } \\
\text { value } \\
\end{array}$ & DF & $\begin{array}{c}\text { A } \\
\text { Sig } \\
\end{array}$ & $\eta 2$ \\
\hline \multirow{8}{*}{ 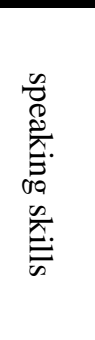 } & \multirow{2}{*}{ Fluency } & Experimental & 30 & 11.17 & 1.69 & \multirow{2}{*}{23.05} & \multirow{2}{*}{58} & \multirow{2}{*}{0.01} & \multirow{2}{*}{0.90} \\
\hline & & Control & 30 & 3.58 & 0.62 & & & & \\
\hline & \multirow{2}{*}{ Accuracy } & Experimental & 30 & 37.38 & 5.93 & \multirow{2}{*}{23.17} & \multirow{2}{*}{58} & \multirow{2}{*}{0.01} & \multirow{2}{*}{0.90} \\
\hline & & Control & 30 & 11.88 & 1.09 & & & & \\
\hline & \multirow{2}{*}{ Comprehensibility } & Experimental & 30 & 19.90 & 3.14 & \multirow{2}{*}{25.03} & \multirow{2}{*}{58} & \multirow{2}{*}{0.01} & \multirow{2}{*}{0.92} \\
\hline & & Control & 30 & 5.30 & 0.61 & & & & \\
\hline & \multirow{2}{*}{ Complexity } & Experimental & 30 & 3.38 & 0.65 & \multirow{2}{*}{12.70} & \multirow{2}{*}{58} & \multirow{2}{*}{0.01} & \multirow{2}{*}{0.74} \\
\hline & & Control & 30 & 1.47 & 0.51 & & & & \\
\hline
\end{tabular}

Table (2) indicates that the mean scores of the study participants of the experimental group in the post administration of the EFL speaking skills was higher than the participants' mean scores of the control group in the EFL fluency skills; where t-value is (23.05) which is significant at the $(0.01)$ level. Also in the EFL accuracy skills where t-value is $(23$. 17). In the EFL comprehensibility skills where t-value is(25. 03), . Also in the EFL complexity skills; where t-value is(12. 70), thus the second hypothesis was supported.

The second hypothesis indicated that "'there is a statistically significant difference at the $(0.01)$ level between the mean scores of the experimental group in EFl speaking skills on the pre and post administration of EFL speaking tests in favor of the post administration. $"$

Table(3): Findings of t-test of the EFL speaking pre-post administration of the experimental group in EFL speaking skills.

\begin{tabular}{||c|c|c|c|c|c|c|c|c|}
\hline The Test & Group & .No & Mean & $\begin{array}{c}\text { Std. } \\
\text { Deviation }\end{array}$ & $\begin{array}{c}\text { t- } \\
\text { value }\end{array}$ & DF & $\begin{array}{c}\text { A } \\
\text { Sig }\end{array}$ & $\boldsymbol{\eta} 2$ \\
\hline $\begin{array}{c}\text { The overall } \\
\text { speaking }\end{array}$ & Post & 30 & 71.83 & 10.89 & 25.09 & 29 & 0.01 & $\begin{array}{c}0 . \\
92\end{array}$ \\
\hline & Pre & 30 & 20.85 & 1.95 & & & & \\
\hline
\end{tabular}

Table (3) indicates that the mean scores of the study participants of the experimental group in the post administration of the EFL speaking test was higher than their scores in the pre administration, where t-value is (25.09) and is significant at the (0.01) level . Consequently, the third 
hypothesis was confirmed.

Table (4): Findings of t-test of the EFL speaking skills pre-post administration in each sub-skill of the experimental group

\begin{tabular}{|c|c|c|c|c|c|c|c|c|c|}
\hline $\begin{array}{l}\text { Main } \\
\text { skills }\end{array}$ & Sub-skills & Group & .No & Mean & $\begin{array}{c}\text { Std. } \\
\text { Deviation }\end{array}$ & $\begin{array}{c}\text { t- } \\
\text { value }\end{array}$ & DF & $\begin{array}{c}\text { A } \\
\text { Sig }\end{array}$ & $\eta 2$ \\
\hline \multirow{8}{*}{ 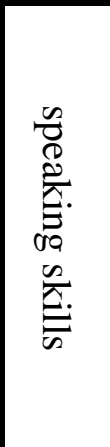 } & \multirow{2}{*}{ Fluency } & Post & 30 & 11.17 & 1.69 & \multirow{2}{*}{24.33} & \multirow{2}{*}{29} & \multirow{2}{*}{0.01} & \multirow{2}{*}{0.91} \\
\hline & & Pre & 30 & 3.30 & 0.52 & & & & \\
\hline & \multirow{2}{*}{ Accuracy } & Post & 30 & 37.38 & 5.93 & \multirow{2}{*}{ 23. 94} & \multirow{2}{*}{29} & \multirow{2}{*}{0.01} & \\
\hline & & Pre & 30 & 11.22 & 0.68 & & & & \\
\hline & \multirow{2}{*}{ Comprehensibility } & Post & 30 & 19.90 & 3.14 & \multirow{2}{*}{26.05} & \multirow{2}{*}{29} & \multirow{2}{*}{0.01} & \\
\hline & & Pre & 30 & 5.03 & 0.13 & & & & 0.92 \\
\hline & \multirow{2}{*}{ Complexity } & Post & 30 & 3.38 & 0.65 & \multirow{2}{*}{13.56} & \multirow{2}{*}{29} & \multirow[b]{2}{*}{0.0} & \\
\hline & & Pre & 30 & 1.30 & 0.47 & & & & 0.10 \\
\hline
\end{tabular}

This table indicates that the mean scores of the experimental group in the post administration of the EFL speaking test was higher than the scores of the pre administration in the EFL speaking skills(fluencyaccuracy-comprehensibility - complexity), which is significant at the $(0$. 01) level.

\section{Discussion of the results:}

In the light of the previous results, it is clear that the experimental group pupils outperformed the control group in the post - treatment. The pupils' oral performance increased after exposing them to different storytelling activities. This may be due to the fact that in storytelling events, the words are not memorized but are received through spontaneous energetic performance, assisted by audience participation (peers) and interaction which implies the relationship between teller and listeners, in fluid interactive space of performance. This result is consistent with (Isabel, Sobol, Lindauer \& Lawrence, 2004). In storytelling, pupils are encouraged to join in repetitive phrases and given the opportunity to suggest variation in certain story elements and aspects. In the digital storytelling, the pupils use more repetitive phrases , sounds and gestures; the case which enhances their imagination as well 
as encourage them to create mental picture of the language elements .

The results of the present study also revealed that the pupils in the experimental group when compared with the control one, are able to speak well after exposing to different storytelling strategies. As novice speakers, they are able to practise the mid proficiency level . This may be due to the fact that digital storytelling enhanced fluency, vocabulary acquisition and comprehensibility skills. This is consistent with Irby (2012) and Smeda, Dakich \& Sharda (2014). Digital_storytelling_serves many purposes.

\section{Conclusions}

From the pevious results, it can be concluded that digtal storytelling is an effective strategy that incorporates the authentic ways of knowing a text into instruction. In addition to improving the performance in the areas of listening and speaking (oral language), digital storytelling has a great impact on second language learning . The effectiveness of digital storytelling may be due to merging a variety of activities and tasks that encouraged the pupils to develop their EFL oral proficiency . At the begging of the intervention, some pupils were not able to speak because of being afraid of negative assessment and making mistakes in pronounciation during speaking English. By using many activities such as role play, taking turns and oral discussion , the pupils' fear of participation decreased.

It can be concluded that using digital storytelling was effective in developing the EFL speaking skill of the experimental group.

\section{Recommendations}

Based on the results of the present study, the following recommendations are presented: 
1- 1-Digital storytelling should be implemented in teaching EFL speaking skills to pupils at the primary stage.

2- Teachers should be trained on the use of technology instead of traditional teaching.

3- Teachers should provide pupils with different types of digital stories to watch and listen to extensively, not only the story they study in the curriculum.

4- Schools should be provided with access to the internet inside the classrooms.

\section{Suggestions for Further Research}

The results of the present study point out the need for conducting the following research:

1- Investigating the effect of digital storytelling on improving EFL speaking skills among learners at other educational levels: preparatory and secondary.

2- Investigating the effect of digital storytelling on other language skills such as reading and writing.

3- Investigating how digital stories can effectively be implemented to support EFL speaking skills and affective variables such as attitude and self-efficacy.

4- Investigating the effectiveness of more recent technology applications in the EFL listening skills. 


\section{References}

- Abdel-Khalk, W. (2011). The effectiveness of using Role Playing Activities on developing some speaking skills for second prep school students . Unpublished M. A. thesis, Institute of Educational studies, Cairo University.

- Ali, H. S. (2010). The Effectiveness of a Self-efficacy based program for developing EFL Oral oral communication skills among prospective teachers. Unpublished Master thesis. Faculty of Education, Benha University.

- Al-Kady, I. (2016). The Effectiveness of a program based on some Natural Approach Activities in Developing EFL oral communication skills among primary school pupils. Unpublished PH. D. thesis, Faculty of Education, Menoufia University.

- Bashir, M. , Azeem, M. \&Dogar, A. H. (2011). Factor Effecting Students' English Speaking Skills . British Journal of Arts and Social Sciences . 2(1), (34-50).

- Boonkit, k. (2010). Enhancing the development of speakin skills for non-native speakers of English. procedia social and behavioral sciences, 2 (2).

- Brown, H, D . (2000). Teaching by principles. An Interactive Approach to Language Pedagogy. Second Edition.

- Bull G, \& Kajder S. (2004). Digital storytelling in the language arts Classroom . Learning \& Leading with Technology, 32(4), pp. 46-49.

- Bygate, M. (2001). Effects of task repetition on the structure and control of oral language. In M. Bygate, P. Skehan \& M. Swain (Eds.), Researching pedagogic tasks: Second language learning, teaching and testing (pp. 23-48). Essex, UK: Pearson Education

- Diyyab, A. (2013). The effectiveness of a blended learning -based program in developing EFLspeaking Skills and reducing anxiety. Unpublished Master Thesis, Faculty of Education , Benha University. 
- El-Basel, A. (2008). The effectiveness of A multimedia program using Animation to develop the speaking skill in English for the pupils of the primary stage. Unpublished Master thesihu s, Institute of Educational Studies, Cairo University.

- Elnada, Z. (2015). The Effectiveness of using Hot Seating Strategy on Enhancing Student -Teacher's Speaking Skills at Al- Azhar University -Gaza. Unpublished Master, Faculty of Education . AlAzhar University . Gaza.

- Farag, M. (2015). Utilizing a computer mediated program in developing EFL primary stage pupil's speaking skills and motivation. Unpublished Master thesis, Faculty of Education, Mansoura University.

- Fuente, M. J. (2003) . IS SLA Interactionist Theory Relevant to CALL? A Study on the Effects of Computer-Mediated Interaction in L2 Vocabulary Acquisition . Computer Assisted Language Learning 16(1).

- Harmer, J. (2010). How to teach English. Harlow, England: Longman.

- Heffernan, N. (2005). Watching Movie Trailers in the ESL class. Ritsumeikan University, Kyoto, Japan. The Internet TESL Journal Vol. XI, No. http://iteslj. org/Lessons/Heffernan-MovieTrailers. html.

- Inoue, C. (2009). Investigating the sensitivity of the measures of fluency, accuracy, complexity and idea units with a narrative task. Papers from the Lancaster University Postgraduate Conference in Linguistics \& Language teaching , 4 134-135. .

- Irby, B. (2012). The effect of a structured story reading intervention, story retelling and higher order thinking for English language and literacy acquisition. Journal of Research in reading, 35(1), 87-113.

- Isbell, R. , Sobol, J., Lindauer, L. \& Lawrence, A. (2004). The effects of storytelling and storyreading on the oral language complexity and comprehension of young children. Early Childhood Education Journal , 32(3), 157-163.

- Jakes, D. (2006). Standards-Proof your digital storytelling efforts. Tec learning. 
- Kayi, H. (2006). Teaching Speaking: Activities to promote speaking in a Second Language. The Internet Tesl Journal, Vol. X11, No. 11(available online at: http://itesl. org/Articles/KayiTeachingSpeaking. html.

- Khatter, S. (2012). The effectiveness of a proposed program based on Shektman Method of Communicative Teaching in developing EFLAdvanced Learners 'Oral Proficiency. Unpublished Doctoral Dissertation, Faculty of Education, Zagazig University

- Luoma, S. (2009). Assessing Speaking . United Kingdom. Cambridge University press.

- Munro, M. \& Derwing, T. (1995). Foreign Accent, Comprehensibility, and Intelligibility in the Speech of Second Language Learners. language learning. 49(1).

- Ozgen, K. \& Bimdak, R. (2012). Examining student opinions on computer use based on the learning styles in mathenatics education. TOJET: The Turkish Online Journal of Educational Technology, 11(1).

- Richards, j. (2006). Communicative Language Teaching Today. Cambridge University Press.

- Riesland, E. (2005). Visual Literacy in the classroom. New horizons for learning.

- Robinson, P. (2001). Task complexity, task difficulty, and task production: Exploring interactions in a componential framework. Applied Linguistics, 23, 27-57.

- Rokni , S. J. \& Qarajeh, M. (2014). Digital storytelling in EFL classrooms: The effect on the oral performance. International Journal of Language and Linguistics. 2(4): 252-257

- Rossiter, M. I, Derwing, T. M., Manimtim, L. G. \& Thomson, R. I. (2010). Oral Fluency: The Neglected Component in the Communicative language Classrom. The Canadian modern language Review. 66, 4. 
- Seif El-Naser, A. (2003). The effectiveness of some language activities on developing English language Listening skills for fifth grade primary pupils. Unpublished M. A. Thesis, Helwan University.

- Selim, M. (2011). The effectiveness of performance assessment in developing the English listening and speaking skills of preparatory pupils. Unpublished PHD Dissertation, Institute of Educational studies, Cairo University.

- Smeda, N., Dakich, E. \& Sharda, N. (2014). The effectiveness of digital storytelling in the classrooms :a comprehensive study. Smart Learning Environment, 1(6).

- Standely, M. (2003). Digital storytelling using new technology and the power of stories to help our students learn and teach. Cable in the classroom.

- Torkey, S., A., E. (2006). The Effectiveness of a task-basd instruction program developing the English language speaking skills of secondary stage students. Unpublished doctoral dissertation, Women's college. Ain Shams University

- UR, P. (2000). A course in Language Teaching :Practice and Theory . Cambridge: Cambridge University Press.

- Virginia, p., R., Wrench, J. S., \& Gorham, J. (2009). A Communication, Affect, and learning in the classroom. (3 $\mathrm{rd}$ ed) USA: Virginia, peck Richmond, Jason Wrench, and Joan Gorham

- West, J (2013). I still cannot speak English . Bookboon. com.

- Wigglesworth, G. (1997). An investigation of planning time and proficiency level on oral test discourse. Language Testing, 14, 167-197.

- Yang, Y. \& Wu, W. (2012). Digital Storytelling for Enhancing Student Academic Achievement, Critical Thinking, and Learning Motivation: A Year-Long experimental study. Computers \& Education 59, 339-352. 